\title{
Organizational Culture and Effectiveness: A Literature Review
}

\author{
Simone Elias Ed.D \\ Michael Akintayo Ph.D \\ Abilene Christian University \\ Texas, USA.
}

\begin{abstract}
This review examined studies concerning organizational culture theory, specifically how it affects the effectiveness of organizations. It starts with an introduction of Denison and Mishra's (1995) model and its use of the terms organizational culture and effectiveness in the field of management of organizations. Subsequently, it presents a table, chronologically organized, introducing significant research that highlighted major traits and developments of organizational culture theory as it relates to effectiveness. Next, beginning with Denison and Mishra's (1995) seminal article, this review discusses how the construct of organizational culture and effectiveness has advanced over the years, nationally and internationally and to various contexts. The examination largely concludes with a discussion of the current state of the organizational culture theory as it relates to effectiveness, addressing possible future developments and potential applications in educational settings.
\end{abstract}

Keywords: organizational culture, effectiveness

\section{Introduction}

Denison and Mishra (1995) groundbreaking research identified a critical gap in the organizational studies literature as it concerned the need for unambiguous theories of organizational culture and effectiveness. Their connection of the terms, "effectiveness" and "organizational culture" utilizing mixed methods, opened the doors for a scholarly discussion of the impact of organizational culture to the effectiveness of organizations. Such scholarly conversation continues to be a work in progress in the 21 st century (Saad \& Abbas, 2018).

Their seminal study, looked into the culture of organizations with a functionalist lens, seeking to, "develop and test a model of the cultural traits that appear to characterize effective organizations" (Denison \& Mishra, 1995, p. 205). The concept challenged the predominant symbolic views of organizational culture at that time (Martin, 2002). Denison and Mishra indicated that often, "culture measures are compared, in most cases, to measures of business performance, defined in financial terms" (p. 206). Along this line of thought, the study substantially advanced the literature of organizational culture by proposing, "building a more general theory of the cultural traits and values associated with effectiveness" and, "test the impacts that these traits have on multiple dimensions of effectiveness" (Denison \& Mishra, 1995, p. 207).

In spite of the criticisms of such a broad view (Smith \& Shilbur, 2004), the indication that organizational culture may have an impact on effectiveness of organizations considering traits and values captured the interest of practitioner and scholars concerned with a holistic view of the phenomenon. While some researchers initially identified some shortcomings on Denison and Mishra's (1995) integrative approach of organizational culture (Martin, 2002), the same researchers later acknowledged that it contributed to the advancement of the literature by offering, "a different kind of insight" (Martin, 2002, p. 254). Overall, Denison and Mishra's (1995) seminal work indeed pioneered and contributed to a series of studies and scholarly discussions in the field of organizational culture, as it is highlighted chronologically on research table 1. 


\section{Seminal Audit Research Table 1.1}

\begin{tabular}{|c|c|c|c|c|}
\hline Article Title & Date/ Journal/ Discipline & Author(s) & Article Synopsis & Article Contributions \\
\hline $\begin{array}{l}\begin{array}{l}\text { Seminal: } \text { Toward a } \\
\text { theory } \\
\text { organizational } \\
\text { culture } \\
\text { effectiveness }\end{array} \\
\begin{array}{lr}\text { Cited by } \\
\text { (Google metrics, } \\
\text { 07/27/19) }\end{array}\end{array}$ & 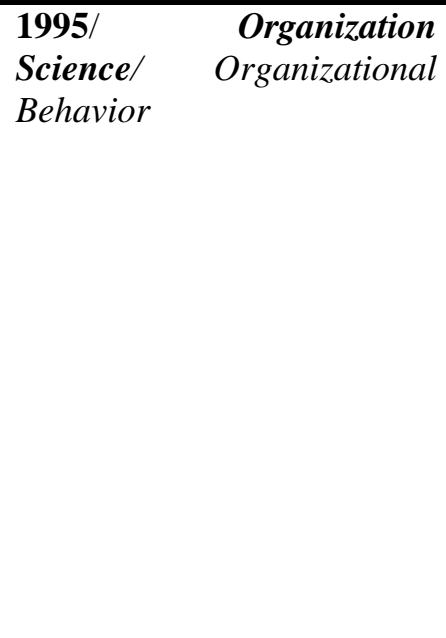 & $\begin{array}{l}\text { Denison, D. R., \& } \\
\text { Professor of } \\
\text { Management and } \\
\text { Organizations } \\
\text { Ph.D. University of } \\
\text { Michigan, } \\
\text { Organizational } \\
\text { Psychology } \\
\text { Mishra, A. K. } \\
\text { Professor of Business } \\
\text { Ph.D. North Carolina } \\
\text { Central University }\end{array}$ & 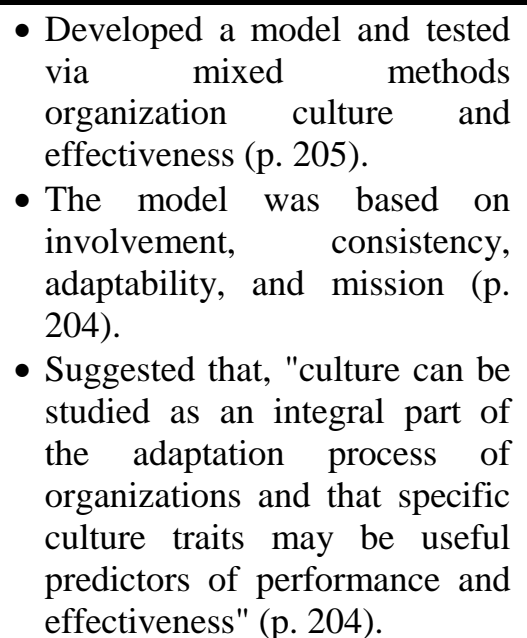 & $\begin{array}{l}\text { Seminal article } \\
\text { - Identified a gap in the literature, } \\
\text { and the need of, "explicit theories } \\
\text { of organizational culture and } \\
\text { effectiveness" (p. 205). } \\
\text { - Attempted to combine"functionalist } \\
\text { and the phenomenological } \\
\text { perspectives" (p. 205). } \\
\text { - Traced a parallel between OC and } \\
\text { "outcomes" (p. 205). } \\
\text { - Advanced the O.C theory by } \\
\text { promoting attention to "the issue of } \\
\text { organizational culture and a a } \\
\text { effectiveness" (p. 205). }\end{array}$ \\
\hline $\begin{array}{l}\text { 1) What is the } \\
\text { difference between } \\
\text { organizational } \\
\text { culture and } \\
\text { organizational } \\
\text { climate? A native's } \\
\text { point of view on a } \\
\text { decade of paradigm } \\
\text { wars. } \\
\text { Theoretical paper }\end{array}$ & $\begin{array}{l}\text { 1996/ The Academy of } \\
\text { Management Review/ } \\
\text { Organizational Behavior }\end{array}$ & $\begin{array}{l}\text { Denison, D. R } \\
\text { Professor } \\
\text { Management } \\
\text { Ph.D. University of } \\
\text { Michigan, } \\
\text { Organizational } \\
\text { Psychology }\end{array}$ & $\begin{array}{l}\text { - It is a response to the reviews } \\
\text { of Denison and } \\
\text { Mishra'sseminal article. } \\
\text { - Pointed out the criticisms } \\
\text { Denison and Mishra'sarticle } \\
\text { received for its positivist and } \\
\text { mixed method approach (p. } \\
642 \text { ). } \\
\text { - In response, the author } \\
\text { clarified the approach } \\
\text { employed in the previous } \\
\text { article, making a connection } \\
\text { between climate and culture in } \\
\text { organizations (p. 619). }\end{array}$ & $\begin{array}{l}\text { - Suggestd that culture and climate } \\
\text { may overlap, however they are two } \\
\text { distinctive entitles, thus clarifying } \\
\text { that the usage of mixed methods to } \\
\text { study OC and effectiveness in } \\
\text { Denison and Mishra's (1995) } \\
\text { article was doable, as it addresses } \\
\text { the first, not the latter. } \\
\text { - Addressed the fact that studies on } \\
\text { culture should not be rejected or } \\
\text { accepted, "because the perceptive } \\
\text { they had taken" (p. 647). }\end{array}$ \\
\hline $\begin{array}{l}\text { 2) Organizational } \\
\text { and strategic } \\
\text { predictors of } \\
\text { manufacturing } \\
\text { technology }\end{array}$ & $\begin{array}{l}\text { 2001/Technovation/Technol } \\
\text { ogy }\end{array}$ & $\begin{array}{l}\text { Stock, G. N., \& } \\
\text { Assistant Professor in } \\
\text { the College of Business } \\
\text { at Northern Illinois } \\
\text { University. } \quad \text { Ph.D. }\end{array}$ & $\begin{array}{l}\text { - Studied } 470 \text { higher-level } \\
\text { executives and managers at a } \\
\text { manufacturing plant. } \\
\text { - Examined,"how organizational } \\
\text { and strategic variables are }\end{array}$ & $\begin{array}{l}\text { - Utilized a similar data collection as } \\
\text { Denison and Mishra's (1995) study. } \\
\text { - AdvancedDenison and Mishra's } \\
\text { (1995) article discussionby } \\
\text { evaluating culture and effectiveness }\end{array}$ \\
\hline
\end{tabular}




\begin{tabular}{|c|c|c|c|c|}
\hline 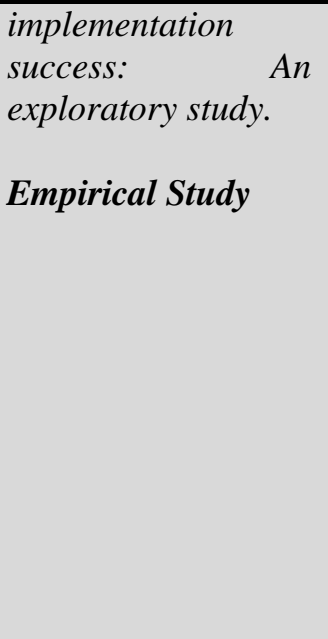 & & $\begin{array}{l}\text { Operations } \\
\text { Management, } \\
\text { University of North } \\
\text { Carolina. McDermott, } \\
\text { C. M. Associate } \\
\text { Professor Lally School } \\
\text { of Management. Ph.D. } \\
\text { Business, University of } \\
\text { North Carolina. }\end{array}$ & $\begin{array}{l}\text { related to success in technology } \\
\text { implementation" (p. 625). } \\
\text { - The authors observed that, } \\
\text { "culture as a factor in } \\
\text { technology implementation has } \\
\text { received little attention" (p. } \\
\text { 626),and call for more studies } \\
\text { addressing, "the relationship } \\
\text { between organizational culture, } \\
\text { operations strategy and } \\
\text { technology implementation } \\
\text { effectiveness" (p. 635). }\end{array}$ & $\begin{array}{l}\text { in the context of manufacturing, } \\
\text { adding the layers of technology and } \\
\text { strategy (p. 626). } \\
\text { - Suggested that future studies } \\
\text { should investigate "strategy and } \\
\text { culture variables" (p. 635). } \\
\text { - The results indicated, "that both } \\
\text { culture and strategy variables are } \\
\text { significant related to technology } \\
\text { implementation" (p. 625). } \\
\text { - Advanced the literature by pointing } \\
\text { out that not only culture has impact } \\
\text { on effectiveness but also } \\
\text { "operations strategy will lead to } \\
\text { positives results" (p. 634). }\end{array}$ \\
\hline $\begin{array}{l}\text { 3) Organizational } \\
\text { culture and } \\
\text { effectiveness: Can } \\
\text { American theory be } \\
\text { applied in Russia? } \\
\text { Empirical study }\end{array}$ & $\begin{array}{l}\text { 2003/Organization Science/ } \\
\text { International Business }\end{array}$ & $\begin{array}{l}\text { Fey, C. F., \& } \\
\text { Professor } \\
\text { International Business } \\
\text { Stockholm School of } \\
\text { Economics } \\
\text { Ph.D. University of } \\
\text { Western Ontario } \\
\text { Denison, D. R } \\
\text { Professor } \\
\text { Management } \\
\text { Ph.D. University of } \\
\text { Michigan, } \\
\text { Organizational } \\
\text { Psychology }\end{array}$ & $\begin{array}{l}\text { - Examined } 179 \text { companies in } \\
\text { Russia, exploring,“the link } \\
\text { between organizational culture } \\
\text { and effectiveness for foreign- } \\
\text { owned firms operating in } \\
\text { Russia" and utilizing Denison } \\
\text { and Mishra's model (p. 686). } \\
\text { - UtilizedDenison and Mishra } \\
\text { "survey items" (p. 691). } \\
\text { - Linked,"functional subcultures, } \\
\text { incompleteness, perspective, and } \\
\text { time pe pelain the } \\
\text { coordination to help explat } \\
\text { differences that we observed in } \\
\text { effectiveness" (p. 702). }\end{array}$ & $\begin{array}{l}\text { - The authors' build"on the } \\
\text { framework developed by Denison } \\
\text { and his colleagues" (p. 688). } \\
\text { - Provided a cross-cultural analysis. } \\
\text { - Advanced the OC theory as it } \\
\text { relates to effectiveness by } \\
\text { expanding the theory in other } \\
\text { settings besides the US, and by } \\
\text { adding new layers to the original } \\
\text { model. } \\
\text { - Modified the model adding the } \\
\text { subculture layer, suggesting that } \\
\text { even though Denison and Mishra } \\
\text { study, "has shown that different } \\
\text { cultural traits are related to different } \\
\text { criteria of effectiveness", their } \\
\text { research in Russia points out that, } \\
\text { "differences in national culture may } \\
\text { influence the specific impact that } \\
\text { the four traits have in Russia" } \\
\text { (p.690). }\end{array}$ \\
\hline
\end{tabular}




\begin{tabular}{|c|c|c|c|c|}
\hline $\begin{array}{l}\text { 4) Culture in family- } \\
\text { owned enterprises: } \\
\text { Recognizing and } \\
\text { leveraging unique } \\
\text { strengths. } \\
\text { Empirical study }\end{array}$ & $\begin{array}{l}\text { 2004/ Family Business } \\
\text { Review/ Management }\end{array}$ & $\begin{array}{l}\text { Denison, D. R } \\
\text { Professor of } \\
\text { Management } \\
\text { Ph.D. University of } \\
\text { Michigan, } \\
\text { Organizational } \\
\text { Psychology } \\
\text { Lief, C., } \\
\text { Ph.D., University } \\
\text { Glasgow, Business } \\
\text { Economy } \\
\text { Family business } \\
\text { Writerat IMD. } \\
\text { Ward, J. L and } \\
\text { Geert, S. } \\
\text { Ph.D., Business, } \\
\text { Stanford. Professor of } \\
\text { Family business }\end{array}$ & $\begin{array}{l}\text { - Utilized Denison and Mishra's } \\
\text { model to study, "the culture } \\
\text { profiles of } 20 \text { family-owned } \\
\text { firms and compares those } \\
\text { results to a larger data archive } \\
\text { of } 389 \text { firms that are not family } \\
\text { owned" (p. 67). } \\
\text { - Examined,"if a family firm's } \\
\text { culture can be operationally } \\
\text { described, contrasted to the } \\
\text { culture of nonfamily firms, and } \\
\text { related to company } \\
\text { performance" (p. 68). } \\
\text { - The findings suggested,"that } \\
\text { family-controlled firms do have } \\
\text { a distinct, performance- } \\
\text { enhancing culture" (p. 68). }\end{array}$ & $\begin{array}{l}\text { - Advanced the OC theory by } \\
\text { applying Denison and Mishra's } \\
\text { model in the context of family } \\
\text { business. } \\
\text { - Traced a parallel between } \\
\text { "disciplines of family business and } \\
\text { organizational behavior" (p. 61). } \\
\text { - Suggested that future studies should } \\
\text { address, "How is culture translated } \\
\text { into strategy and business } \\
\text { performance" (p. 68). } \\
\text { - Advanced OC by suggesting that } \\
\text { family owned companies are } \\
\text { effective "because of who they are" } \\
\text { and "what they do strategically" (p. } \\
\text { 61), thus validating the importance } \\
\text { of strategy, discussed in previous } \\
\text { conversations cited in this table, } \\
\text { (e.g. Stock \& McDermott, 2003). }\end{array}$ \\
\hline
\end{tabular}




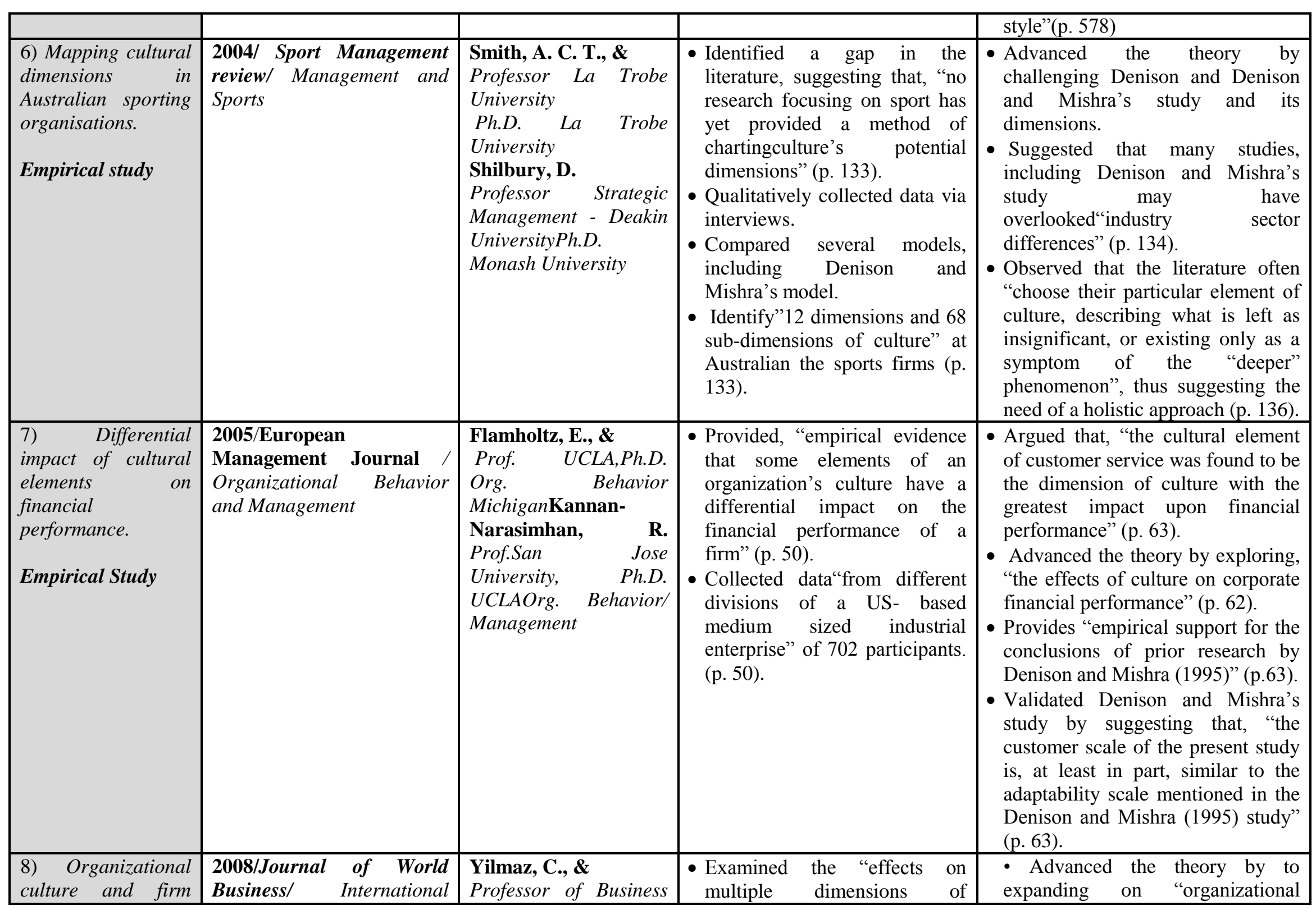




\begin{tabular}{|c|c|c|c|c|}
\hline $\begin{array}{l}\text { effectiveness: An } \\
\text { examination of } \\
\text { relative effects of } \\
\text { culture traits and } \\
\text { the balanced culture } \\
\text { hypothesis in an } \\
\text { emerging economy. } \\
\text { Empirical Study }\end{array}$ & Business & $\begin{array}{l}\text { Bogāzici University. } \\
\text { Ergun, E. } \\
\text { Professor of } \\
\text { management Gebze } \\
\text { Institute of Technology }\end{array}$ & $\begin{array}{l}\text { effectiveness" utilizing } \\
\text { Denison's model and scale. } \\
\text { - Looked at quantitatively at, } \\
\text { "100 firms representing 18 } \\
\text { major manufacturing industries } \\
\text { in Turkey" (p. 291). } \\
\text { - Suggested that the results are, } \\
\text { "in line" and "consistent with } \\
\text { the findings in western } \\
\text { contexts"(p. 300). }\end{array}$ & $\begin{array}{l}\text { culture elements with } \\
\text { effectiveness" utilizing Denison's } \\
\text { model in Turkey (p. 291). } \\
\text { - Provided validation of Denison's } \\
\text { model and survey by having as a } \\
\text { base the study on "Denison's theory } \\
\text { of organizational culture and } \\
\text { effectiveness" (p. 291). } \\
\text { - Contributed to the OC literature } \\
\text { by, "examining the effects" of } \\
\text { Denison's model } \\
\text { considering"several dimensions of } \\
\text { organizational effectiveness" in } \\
\text { Turkey (p. 300). }\end{array}$ \\
\hline 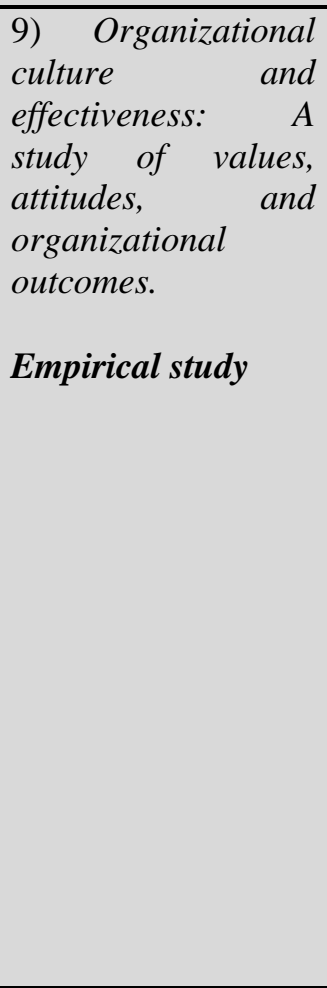 & $\begin{array}{l}\text { 2009/Journal of } \begin{array}{c}\text { Business } \\
\text { Research/ }\end{array} \text { Business } \\
\text { Management }\end{array}$ & $\begin{array}{l}\text { Gregory, B. T., } \\
\text { Professor of Business, } \\
\text { Northern Arizona } \\
\text { University. } \\
\text { Armenakis, A. A., } \\
\text { \&Professor Auburn } \\
\text { University College of } \\
\text { BusinessShook B, C. } \\
\text { L.Professor Auburn } \\
\text { University College of } \\
\text { Business }\end{array}$ & $\begin{array}{l}\text { - Examined,"employee attitudes" } \\
\text { in99 healthcare sitesin the US } \\
\text { (p. 673). } \\
\text { - Concurs with Denison and } \\
\text { Mishra that OCthat place } \\
\text { emphasis on certain group } \\
\text { values are more effective, and } \\
\text { that,"cultural balance is } \\
\text { positively related to employee } \\
\text { satisfaction"(p. 674). } \\
\text { - Argued that, "the group domain } \\
\text { appears to be a more consistent } \\
\text { predictor of effectiveness than } \\
\text { the other three domains" (p. } \\
\text { 675). }\end{array}$ & $\begin{array}{l}\text { - Advanced the theory of by } \\
\text { suggesting that scholars } \\
\text { should,"identify other mediating } \\
\text { variables in the culture- } \\
\text { effectiveness relationship" in order } \\
\text { to fully understand how an } \\
\text { "organization's culture has an } \\
\text { impact on its effectiveness" (p. } \\
\text { 679). } \\
\text { - Supported, "that the group domain } \\
\text { has a significant impact on the } \\
\text { effectiveness of the organization" } \\
\text { (p. 678). } \\
\text { - Suggested that,"employee attitudes } \\
\text { mediate the culture- effectiveness } \\
\text { relationship" (p. 673). } \\
\text { - Advanced the literature by looking } \\
\text { deeper into the "impact of the } \\
\text { group domain and cultural balance } \\
\text { on organizational effectiveness" (p. } \\
\text { 675). } \\
\text { - Advances the theory by expanding } \\
\text { to the health care field. }\end{array}$ \\
\hline
\end{tabular}




\begin{tabular}{|c|c|c|c|c|}
\hline $\begin{array}{l}\text { 10)Linking } \\
\text { organizational } \\
\text { culture, structure, } \\
\text { strategy, and } \\
\text { organizational } \\
\text { effectiveness: } \\
\text { Mediating role of } \\
\text { knowledge } \\
\text { management. } \\
\text { Empirical study }\end{array}$ & $\begin{array}{l}\text { 2010/ Journal of Business } \\
\text { Research } \\
\text { Business and Human } \\
\text { Resources }\end{array}$ & $\begin{array}{l}\text { Zheng, W., } \\
\text { Prof. HR- Northern } \\
\text { Illinois Ph.D. Zheiang } \\
\text { Un. } \\
\text { Yang, B., \& } \\
\text { Prof.HRM and Org. } \\
\text { Behavior, Tsinghua } \\
\text { Ph.D. HRM University } \\
\text { of Georgia } \\
\text { McLean, G. N. } \\
\text { Prof. of HRTexas } \\
\text { A\&M University }\end{array}$ & $\begin{array}{l}\text { - Examined quantitativelyvia } \\
\text { survey1585HR professionals in } \\
301 \text { organizations. } \\
\text { - Utilized Denison and Mishra's } \\
\text { model and an adaptation of its } \\
\text { survey. } \\
\text { - Explored, "the possible } \\
\text { mediating role of knowledge } \\
\text { management in the relationship } \\
\text { between organizational culture, } \\
\text { structure, strategy, and } \\
\text { organizational effectiveness" } \\
\text { (p. 763). }\end{array}$ & $\begin{array}{l}\text { - Advanced the literature by } \\
\text { providing a different perspective on } \\
\text { Denison and Mishra's study takes, } \\
\text { suggesting that OC,"does not } \\
\text { directly lend its influence on } \\
\text { organizational effectiveness; rather, } \\
\text { it exerts its influence through } \\
\text { shaping the behavior of } \\
\text { organizational members" (p. 765). } \\
\text { - The results suggest that, } \\
\text { "knowledge management can } \\
\text { influence organizational } \\
\text { effectiveness when it is in } \\
\text { alignment with organizational } \\
\text { culture, structure, and strategy" (p. } \\
\text { 769). Advances the field by pointing out } \\
\text { the importance of studying } \\
\text { structure when studying OC } \\
\text { effectiveness. }\end{array}$ \\
\hline
\end{tabular}




\begin{tabular}{|c|c|c|c|c|}
\hline $\begin{array}{l}\text { organizational } \\
\text { effectiveness: } \\
\text { A meta-analytic } \\
\text { investigation of the } \\
\text { competing values } \\
\text { framework's } \\
\text { theoretical } \\
\text { suppositions. } \\
\text { Empirical study }\end{array}$ & Organization Behavior & $\begin{array}{l}\text { State Ph.D. } \\
\text { Management - } \\
\text { Org.Behavior, Ou, A. } \\
\text { Y., } \\
\text { \&Prof.SingaporePh.D. } \\
\text { Management -Arizona } \\
\text { State Kinicki, A. } \\
\text { D.B.A. Kent State Prof. } \\
\text { Arizona State }\end{array}$ & $\begin{array}{l}\text { effectiveness (p. 682). } \\
\text { - Utilized meta-analysis to } \\
\text { examine“organizational culture } \\
\text { theory as well as culture's } \\
\text { relationship with firm } \\
\text { effectiveness" (p.678). } \\
\text { - Adapted a competing values } \\
\text { framework for the } \\
\text { investigation, and compare it } \\
\text { with the Denison and } \\
\text { Mishra'sstudy. }\end{array}$ & $\begin{array}{l}\text { other models to study culture and } \\
\text { effectiveness. } \\
\text { - Agreed withDenison and Mishra's } \\
\text { study that, "culture is a key } \\
\text { ingredient of organizational } \\
\text { effectiveness" (p. 678). } \\
\text { - Suggested that the results of the } \\
\text { study are consistent Denison and } \\
\text { Mishra's findings that, "cultures } \\
\text { should exhibit a positive } \\
\text { association with financial } \\
\text { effectiveness" (p. 682) }\end{array}$ \\
\hline $\begin{array}{l}\text { 13) Organizational } \\
\text { effectiveness: } \\
\text { American } \\
\text { subsidiaries in } \\
\text { Romania } \\
\text { Empirical study }\end{array}$ & $\begin{array}{l}\text { 2011/ Journal of } \\
\text { International Business and } \\
\text { Economy/Business and } \\
\text { Management }\end{array}$ & $\begin{array}{l}\text { Banto, A., \& } \\
\text { Professor of } \\
\text { Management } \\
\text { Argosy University, } \\
\text { Chandan, H. } \\
\text { Professor of Business } \\
\text { Argosy University, }\end{array}$ & $\begin{array}{l}\text { - Examined51 U.S. firms in } \\
\text { Romania. } \\
\text { - Addresses"associations } \\
\text { between the independent } \\
\text { variables" using the Denison } \\
\text { and Mishra's OC survey and } \\
\text { model. } \\
\text { - The study supported Denison } \\
\text { and Mishra's notion, "that there } \\
\text { is a link between organizational } \\
\text { culture and performance" (p. } \\
\text { 46). }\end{array}$ & $\begin{array}{l}\text { - Provided empirical support for in } \\
\text { an international setting for Denison } \\
\text { and Mishra's OC survey and model } \\
\text { of organizational culture and } \\
\text { effectiveness. } \\
\text { - Concurs with Denison and Mishra's } \\
\text { study that the four organizational } \\
\text { culture traits in their model have a } \\
\text { positive influence on effectiveness } \\
\text { of organizations (p. 46) }\end{array}$ \\
\hline $\begin{array}{l}\text { 14)Do consistent } \\
\text { corporate cultures } \\
\text { have better business } \\
\text { performance? } \\
\text { Exploring the } \\
\text { interaction effects } \\
\text { Empirical Study }\end{array}$ & $\begin{array}{l}\text { 2012/ Human Relations/ } \\
\text { Human Resources and } \\
\text { Management }\end{array}$ & $\begin{array}{l}\text { Kotrba, L. M., } \\
\text { Denison Consulting } \\
\text { Gillespie, M. A., } \\
\text { University of South } \\
\text { Florida } \\
\text { Schmidt, A. M., } \\
\text { The University of } \\
\text { Minnesota } \\
\text { Smerek, R. E., } \\
\text { Northwestern } \\
\text { University } \\
\text { Ritchie, S. A., \& } \\
\text { Novo Nordisk Inc., } \\
\text { Denison, D. R. } \\
\end{array}$ & $\begin{array}{l}\text { - Collecteddata from } 88,879 \\
\text { participants in } 137 \text { public } \\
\text { companies. } \\
\text { - Utilized an adapted version of } \\
\text { the Denison'sOC Survey and } \\
\text { model. } \\
\text { - Outlines ideas for potential } \\
\text { future research. } \\
\text { - Presented, "an empirical } \\
\text { demonstration of the } \\
\text { importance of the interaction } \\
\text { among cultural dimensions on } \\
\text { performance" (p. 258). }\end{array}$ & $\begin{array}{l}\text { - Advanced the theory by } \\
\text { acknowledging that, Denison and } \\
\text { Mishra's study may be incomplete } \\
\text { and, "the links between specific } \\
\text { cultural traits and specific } \\
\text { performance outcomes represent } \\
\text { significant progressbut it may also } \\
\text { present an overly simplistic view of } \\
\text { culture's impact on performance" } \\
\text { (p. 242). } \\
\text { - Suggested that the earlier finds of } \\
\text { Denison and Mishra's studymay } \\
\text { not give a complete picture, and }\end{array}$ \\
\hline
\end{tabular}




\begin{tabular}{|c|c|c|c|c|}
\hline & & Prof. IIMD & & $\begin{array}{l}\text { indicate that even thoughthe } \\
\text { "interplay between various aspects } \\
\text { of an organization's cultureis } \\
\text { important" (p. 257), "there is still } \\
\text { much to learn about how various } \\
\text { culture traits combine to predict } \\
\text { organizational outcomes" (p. 257). }\end{array}$ \\
\hline $\begin{array}{l}\text { 15)Organizational } \\
\text { culture in hotel } \\
\text { industry: } \\
\text { Perceptions and } \\
\text { preferences among } \\
\text { staff. } \\
\text { Empirical study }\end{array}$ & $\begin{array}{l}\text { 2013/Advances in } \\
\text { Management/ Human } \\
\text { Resources Management }\end{array}$ & $\begin{array}{l}\text { Mushtaq, A. L., } \\
\text { Fayyaz, A. S., \& } \\
\text { Tanveer } \\
\text { Management } \\
\text { Professors, University } \\
\text { of Kashmir, Srinagar. }\end{array}$ & $\begin{array}{l}\text { - Conducted a study with } \\
\text { 20hotelsin Kashmir valley. } \\
\text { - Suggested that, "culture } \\
\text { provides a base for } \\
\text { understanding the differences } \\
\text { that may exist between } \\
\text { successful firms operating in } \\
\text { the same national culture and } \\
\text { differentiates truly high } \\
\text { performing organizations from } \\
\text { others" (p. 55). }\end{array}$ & $\begin{array}{l}\text { - Advanced the OC literature by } \\
\text { extending the studies of OC and } \\
\text { effectiveness to the Asia continent, } \\
\text { and by including the service sector. } \\
\text { - Suggested that OC, "is what } \\
\text { distinguishes one successful } \\
\text { company from the others" (p. 56). } \\
\text { - Advanced the theory on OC by } \\
\text { suggesting that, "collaboration, } \\
\text { employee focus, knowledge-sharing } \\
\text { and team work are the key cultural } \\
\text { characteristics in the best } \\
\text { performing" companies in the } \\
\text { tourism sector in the Kashmir } \\
\text { valley (p. 56). }\end{array}$ \\
\hline $\begin{array}{l}\text { 16) The impact of } \\
\text { organizational } \\
\text { culture on job } \\
\text { performance: a } \\
\text { study of Saudi } \\
\text { Arabian public } \\
\text { sector work culture. } \\
\text { Empirical study }\end{array}$ & $\begin{array}{l}\text { 2018/Problems } \\
\text { Perspectives } \\
\text { Management }\end{array}$ & $\begin{array}{l}\text { Saad, G. B., \& Abbas, } \\
\text { M. } \\
\text { Management } \\
\text { Professors, } \\
\text { College, Prince Sattam } \\
\text { Bin Abdulaziz } \\
\text { University }\end{array}$ & $\begin{array}{l}\text { - Qualitatively examined OC and } \\
\text { effectiveness ofhigher } \\
\text { education institutions in the } \\
\text { Saudi context. } \\
\text { - Suggested that, "The results of } \\
\text { our research indicate a positive } \\
\text { association between } \\
\text { organization culture and job } \\
\text { performance" (p. 216) } \\
\text { - Proposed that, "the university } \\
\text { should make necessary } \\
\text { measures in order to allow } \\
\text { changes in the organization and } \\
\text { appreciate goals' achievers" (p. } \\
\text { 216). } \\
\end{array}$ & $\begin{array}{l}\text { - Advanced the OC literature by } \\
\text { extending the studies of OC and } \\
\text { effectiveness to the Saudi higher } \\
\text { education context. } \\
\text { - Recommended that future research } \\
\text { should, "evaluate separately the } \\
\text { impact of each element of } \\
\text { organizational culture on } \\
\text { performance" (p. 216). }\end{array}$ \\
\hline
\end{tabular}




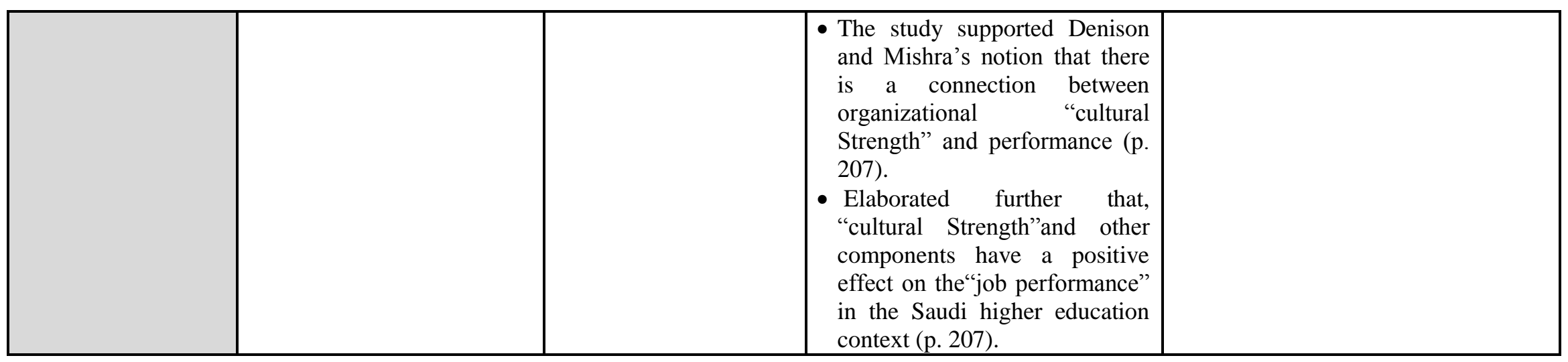

\section{Denison and Mishra's Research}

Denison and Mishra (1995) traced a parallel between organizational culture and the organization's "outcomes" (p. 205). The study presented not only a fulfillment of a gap in the literature as it concerned organizational culture and effectiveness in various contexts but also offered a ground-breaking integration of the "functionalist and the phenomenological perspectives" (Denison \& Mishra, 1995, p. 205).

In their seminal study, the authors developed and tested, via mixed methods, an organizational culture and effectiveness model they developed along with a survey based on four components: (1) involvement, (2) consistency, (3) adaptability, and (4) mission (Denison \& Mishra, 1995, p. 204). In this light, Denison and Mishra advocated that "culture can be studied as an integral part of the adaptation process of organizations and that specific culture traits may be useful predictors of performance and effectiveness" (p. 204). The authors advanced the organizational culture theory by promoting attention to the concept of organizational culture and effectiveness, and by offering a different perspective to the field of organizational studies.

In summary, Denison and Mishra's (1995) study provided an essential contribution to the field of organizational culture. Ultimately, Denison and Mishra's research not only advanced OC in terms of presenting a groundbreaking connection of organizational culture and effectiveness with functionalist and the phenomenological viewpoints, but also by integrating both quantitative and qualitative methods.

\subsection{The Evolution of Denison and Mishra's Research}

In the past decades, Denison and Mishra's (1995) cutting-edge study of organizational culture and effectiveness of organizations has evolved into a scholarly discussion that continues to be a work in progress. Over the years, Denison and Mishra's study has received clarification of terms (Denison, 1996), criticisms (Smith \& Shilbur, 2004; Berg \& Wilderom, 2004), and empirical support (Banto \& Chandan, 2011; Hartnell, Ou \& Kinicki, 2011). In addition, Denison and Mishra's study has been adapted and explored not only theoretically, but also via empirical studies. Scholars, such as Stock and McDermott (2001), concur with Denison and Mishra's research that organizational culture impacts operation and processes of organizations in many ways (p. 626), while others advanced the theory by challenging Denison and Mishra's study and its dimensions (Smith \& Shilbury, 2004). In this light, the authors observed that scholars, such as Denison and Mishra, "choose their particular element of culture, describing what is left as insignificant, or existing only as a symptom of the 'deeper' phenomenon", thus suggesting the need of a more holistic approach (Smith \& Shilbury, 2004, p. 136). 
Attempting to expand and decipher the phenomenon, scholars have conducted studies seeking to validate and to test it nationally (Hartnell, Ou \& Kinicki, 2011; Gregory, Harris, Armenakis \& Shook, 2009), internationally (Banto \& Chandan, 2011; Saad \& Abbas, 2018; Smith \& Shilbury, 2004; Zheng, Yang \& McLean, 2010), and in various sectors and industries (Mushtaq, Fayyaz, \& Tanveer, Saad \& Abbas, 2018; Smith \& Shilbury, 2004). For example, Yilmaz and Ergun (2008) advanced the theory by expanding on the organizational culture, and effectiveness constructs utilizing Denison and Mishra's model and applying it in organizations located in Turkey (p. 291).

Yilmaz and Ergun (2008) examined the, "effects on multiple dimensions of effectiveness" in organizations utilizing the Denison and Mishra's model and scale, looking quantitatively at 100 manufacturing industries in Turkey (Yilmaz \& Ergun, 2008, p. 291). In this study, the results appear to be "in line" and "consistent with the findings in western contexts" that the Denison and Mishra's study presented earlier in 1995 (p. 300).

Mushtaq, Fayyaz, and Tanveer (2009) conducted a study with 20 hotels in Kashmir Valley. The study suggested that organizational culture offers a foundation for the comprehension of, "the differences that may exist between successful firms operating in the same national culture" (Mushtaq et al., p. 55), such comprehension of differences may aid to distinguish a high performing organization from a low performing one (Mushtaq et al., p. 55). In a similar vein, Banto and Chandan (2011) examined 51 U.S. organizations in Romania. Banto and Chandan addressed the relations among independent organizational culture variables using the Denison and Mishra organizational culture survey and model (p. 46). The study supported Denison and Mishra's notion of possible connections between organizational culture and effectiveness of organizations (Banto \& Chandan, 2011).

Fey and Denison (2003) examined 179 companies in Russia, exploring connections between organizational culture and effectiveness in foreign-owned organizations in Russia, also utilizing Denison and Mishra's model. The study sheds light to the construct by providing an interesting cross-cultural analysis of the phenomenon, and by modifying the original model, adding a "subculture" stream to the construct (Fey \& Denison, 2003, p. 690). Even though Denison and Mishra's study revealed that each cultural dimension of the model is associated with a specific criterion of performance, their research in Russia points out that, "differences in national culture" in Russian organizations might affect the potentialities of the four dimensions of Denison and Mishra's model in organizations in that country, and that subcultures should be considered in future studies of Russian organizations (Fey \& Denison, 2003, p. 690).

It is important to note that the contribution of Denison and Mishra's (1995) article in the field of organizational studies appears to go beyond the illumination of the construct of organizational culture and effectiveness in organizations. For instance, it also contributed to demystify the often symbolic perceptive linked to organizational culture studies in the early 1900's (Denison, 1996, p. 647). In this vein, scholars have advanced Denison and Mishra's research by addressing the fact that studies on culture should not be rejected or accepted, "because the perceptive they had taken" (Denison, 1996, p. 647). The study suggested that a positivist view of organizational culture has led to an advancement of the field. In addition, it stated that after Denison and Mishra's publication, research on organizational culture has been recognized and is, "being published in the leading organizational culture journals, only by emulating the same positivist research model culture researchers originally deployed" (Denison, 1996, p. 644).

\section{The Discussion on Organizational Culture late 1990s earlier 2000s}

The end of the 20th century and beginning of the 21st century have brought an intense and thought-provoking discussion among scholars regarding organizational culture and effectiveness, as it concerns the best methodology to study it and what additional variables should be considered in future studies as the concepts of organizational culture and effectiveness progresses in various contexts. In terms of the methodology to study it, in response to the reviews of Denison and Mishra's seminal article, Denison (1996) pointed out the criticisms Denison and Mishra's article received in 1995 for its positivist and mixed-method approach (p. 642). Denison (1996) clarified the approach employed in the article the author wrote with Mishra in 1995, by making connections and analogies about culture and climate in organizations, thus pointing out the importance of "dialogue", between integrative and interpretative studies (Denison and Mishra, 1995, p. 642).

Similarly, Stock and McDermott (2001) supported Denison and Mishra's methodology selection by suggesting that their study findings in their own study of 470 executives and managers at a manufacturing plant appear to be coherent "with Denison and Mishra's (1995) study of organizational culture and effectiveness" (p. 629). Despite its support, other scholars, such as Berg and Wilderom (2004), call for a more "creative" and "for a particular way of defining and measuring" organizational culture (p. 580). The authors advanced the theory by calling for a change in the way researchers study organizational culture and effectiveness (Berg \& Wilderom, 2004, p. 579).

Furthermore, to contribute to the conversation as it concerns the addition of variables to be considered as the study of 
organizational culture and effectiveness, Stock and McDermott (2001) advanced Denison and Mishra's (1995) discussion by presenting conclusions suggesting that, "both culture and strategy are linked to different types of outcomes" (p. 635). The authors also provided additional variables that may be considered to the study of OC and effectiveness, pointing out that a future study should also investigate strategy and organizational culture as it relates to effectiveness (Stock \& McDermott, 2001, p. 635).

In a different vein, Flamholtz and Kannan-Narasimhan (2005) partially concur with the Denison and Mishra's (1995) study, suggesting that only, "some of the elements of an organization's culture" impact effectiveness (p. 52). Flamholtz and Kannan-Narasimhan advanced the theory by concluding, "that not all dimensions of culture are equal; some are more equal than others, or have a greater differential" in the effectiveness of organizations (p. 63). Other scholars, such as Stock and McDermott (2001), emphasized that not only culture has an impact on effectiveness but also, "operations strategy will lead to positive results" (p. 634). By evaluating culture and effectiveness in the context of manufacturing, the authors suggested that "technology", and "strategy" should also be considered as the study of organizational culture and effectiveness progresses (Stock \& McDermott, 2001, p. 626). In response, later studies in the field endeavored to address the variants Stock and McDermott, (2001) suggested. For instance, Denison, Lief and Ward's (2004) study, as well as Zheng et al.'s (2010) investigation, included aspects of strategy into their studies of organizational culture and effectiveness.

\subsection{Organizational Culture and Effectiveness in the 21st century}

The 21st century also brought a noteworthy development in the field of organizational studies as it relates to organizational culture and its impact on the effectiveness of organizations as it concerns research and practice. Kotrba, Gillespie, Schmidt, Smerek, Ritchie and Denison (2012) conducted a large-scale study collecting data from 88,879 participants in 137 public companies. In the study, the authors provided a different perspective to Denison and Mishra's (1995) study conducted more than a decade earlier by adding extra importance of "consistency" in organizations when studying organizational culture and effectiveness, and by exploring the, "idea that the effects of cultural consistency on organizational performance may differ depending on the levels of other culture traits" (Kotrba et al., 2012, p. 64). Kotrba et al. (2012) suggested that earlier finds of Denison and Mishra's study did not provide a complete picture, and indicated that even though the "interplay between various aspects of an organization's culture is important", one needs to be careful when studying organizational culture as, "there is still much to learn about how various culture traits combine to predict organizational outcomes" (p. 257).

The 21st century advanced the literature slowly, but steadily, providing new directions and emergence of new variables to study the phenomenon in research and practice. Conversely, presetting limitations, perspectives, and possibilities for future research and practice, scholars, such as Banto and Chandan (2011), suggested that future researchers interested in contributing to the understanding of the organizational culture literature as it concerns its effectiveness, should seek to explore the relationships between organizational culture and effectiveness of organizations and if those are consistent or not in different organizations. Complementing the suggestions of Kotrba et al. (2012) as it concerns the inclusions of different perspectives to the study of organizational culture, Banto and Chandan (2011) proposed that instead of approaching the impact of organizational culture on "performance outcomes", it may be noteworthy to explore the, "idea that the effects of cultural consistency on organizational performance may differ depending on the levels of other culture traits" (p. 64). In this vein, the authors also recommended that future research should address aspects of human resources in organizations such as cooperation among members and teamwork characteristics (Banto \& Chandan, 2011, p. 56).

Asif (2011) provided a comprehensive literature review and, "an analytical overview of the academic contribution that Denison's article makes across disciplinary and interdisciplinary research" (p. 455). Asif's review provided theoretical support for the methods utilized by Denison and Mishra study in 1995. The author's review of the impact of Denison's (2016) study provided some clarification of Denison and Mishra's article, indicating that the latter provides more significant integration of "disciplinary and interdisciplinary" fields (Asif, 2011, p. 455).

Most recently, the study of the construct has been expanding to the higher education field internationally. Saad and Abbas (2018) qualitatively examined organizational culture and effectiveness of higher education institutions in the Saudi context. The study supported Denison and Mishra's notion that there is a connection between organizational "cultural Strength" and performance (p. 207) and explains further that, "cultural Strength" and other components have a positive effect on the "job performance" in the Saudi higher education context (p. 207). The study also suggested that, "The results of our research indicate a positive association between organization culture and job performance" (p. 216).

The study recommended that future research should, "evaluate separately the impact of each element of organizational 
culture on performance" (p. 216), and it opens the doors for more studies of organizational culture and effectiveness in higher education.

\section{Conclusion}

In this seminal audit paper, the researchers presented a briefly review of the concept of the advancement of organizational culture and effectiveness, from its conception to the present, by examining and summarizing different theoretical and empirical studies that highlighted various stages that the construct has passed through, in addition to its recent developments, contexts, and methods of study. The theory started with a controversial, for that time, mixedmethods approach, and throughout the years, as scholars engaged in discussions, more dimensions, perspectives, and methods of study were added to the investigation of the theory in various contexts. Scholars such as Banto and Chandan (2011) appear to endorse that the original theory of Denison and Mishra succeeded in fulfilling its theoretical and empirical promises in 1995. Other scholars, such as Smith and Shilbur (2004) appear to criticize the practicality of Denison and Mishra's model.

The study of the construct of organizational culture and effectiveness is certainly very thought-provoking, and its applications and importance in higher education organizations seem boundless. The possibilities of testing the organizational culture and its effectiveness in different settings, such as in higher education institutions in the US, particularly within various departments seem important as higher education institutions are opening their doors to a range of occupations (instructional designers, adjuncts, advisors) in the online contexts with employees based in various states and countries. To this end, Saad and Abbas (2018) study could and should be replicated in the higher education institutions in the US.

This construct could also be used to examine the organizational culture newly developed higher education online departments and its effects on student's performance utilizing the adapted model of Denison and Mishra's seminal model presented in this paper. It would also be interesting to conduct a comparative study addressing organizational culture and job effectiveness of online higher education in various countries.

It would also be noteworthy to investigate the organizational culture effects, if any, on the learning outcomes of students in face-to-face environments and online higher education environments considering the subcultures and the leadership that may exist in specific departments and units. A study of this nature could contribute to the advancement of the literature concerning leadership, organizational culture, and effectiveness of higher education. To this end, such a study may contribute to the advancement of Denison and Mishra's model and Banto and Chandan's (2011) indication, "that there is a link between organizational culture and performance" (p. 46). The literature search, reviews and the construct of organizational culture, leadership, and effectiveness appear to show that no known studies have fully addressed this sector thus far in online higher education institutions in the U.S. Such study could potentially serve to refine, improve and further expand this scholarly discussion to this emerging, yet important educational context.

\section{References}

Asif, F. (2011). Estimating the impact of Denison's (1996). What is the difference between organizational culture and organizational climate? A native's point of view on a decade of paradigm wars. Journal of Business Research, 64(1), 454-459.

Banto, A., \& Chandan, H. (2011). Organizational effectiveness: American subsidiaries in Romania.Journal of International Business and Economy, 12(2), 43-61.

Berg, P. T. V. D., \& Wilderom, C. P. M. (2004). Defining, measuring, and comparing organisational cultures.Applied Psychology, 53(4), 570-582.

Denison, D. R., \& Mishra, A. K. (1995). Toward a theory of organizational culture and effectiveness. Organization Science, 6(2), 204-223.

Denison, D. R. (1996). What is the difference between organizational culture and organizational climate? A native's point of view on a decade of paradigm wars.The Academy of Management Review, 21(3), 619-654.

Denison, D. R., Lief, C., \& Ward, J. L. (2004). Culture in family-owned enterprises: Recognizing and leveraging unique strengths. Family Business Review, 17(1), 61-70.

Fey, C. F., \& Denison, D. R. (2003). Organizational culture and effectiveness: Can American theory be applied in Russia?. Organization Science, 14(6), 686-706.

Flamholtz, E., \& Kannan-Narasimhan, R. (2005). Differential impact of cultural elements on financial performance. European Management Journal, 23(1), 50-64.

Gregory, B. T., Harris , S. G., Armenakis, A. A., \& Shook, B, C. L. (2009). Organizational culture and effectiveness: A study of values, attitudes, and organizational outcomes. Journal of Business Research, 62(1), 673-679. 
Hartnell, C. A., Ou, A. Y., \& Kinicki, A. (2011). Organizational culture and organizational effectiveness: A metaanalytic investigation of the competing values framework's theoretical suppositions. Journal of Applied Psychology, 96(4), 677-694.

Kotrba, L. M., Gillespie, M. A., Schmidt, A. M., Smerek, R. E., Ritchie, S. A., \& Denison, D. R. (2012). Do consistent corporate cultures have better business performance? Exploring the interaction effects.Human Relations, 65(2), 241-262.

Martin, J. (2002). Organizational culture:Mapping the terrain. Thousand Oaks, CA: Sage Publications.

Mushtaq, A. L., Fayyaz, A. S., \& Tanveer, A. (2013). Organizational culture in hotel industry: Perceptions and preferences among staff. Advances In Management, 6(5), 55-60.

Saad, G. B., \& Abbas, M. (2018). The impact of organizational culture on job performance: a study of Saudi Arabian public sector work culture. Problems and Perspectives in Management, 16(3), 207

Smith, A. C. T., \& Shilbury, D. (2004). Mapping cultural dimensions in Australian sporting organisations.Sport Management Review, 7(1), 133-165.

Stock, G. N., \& McDermott, C. M. (2001). Organizational and strategic predictors of manufacturing technology implementation success: An exploratory study.Technovation, 21(10), 625-636.

Yilmaz, C., \& Ergun, E. (2008). Organizational culture and firm effectiveness: An examination of relative effects of culture traits and the balanced culture hypothesis in an emerging economy. Journal of World Business,43(1), 290-306.

Zheng, W., Yang, B., \& McLean, G. N. (2010). Linking organizational culture, structure, strategy, and organizational effectiveness: Mediating role of knowledge management. Journal of Business Research, 63(1), 763-771. 